\title{
The involvement of marine tourism companies in CSR: the case of the island of Tenerife
}

\author{
Olga González-Morales ${ }^{1}$ (ID · Agustín Santana-Talavera ${ }^{1} \cdot$ David Domínguez-González $^{1}$
}

Received: 23 May 2020 / Accepted: 23 November 2020 / Published online: 6 February 2021

(c) Springer Nature B.V. 2021

\begin{abstract}
Corporate Social Responsibility is a voluntary strategy by companies, which integrates a set of actions that contribute to sustainable development. This study analyzes the degree of involvement of marine tourism companies in human resource management, adaptation to change, environmental management, local community development and collaboration with public and private agents. These areas configure companies' Corporate Social Responsibility strategies. Information was collected from marine tourism companies on the island of Tenerife using quantitative and qualitative methodologies. A binary logistic regression analysis was applied. The results indicate that, in general, marine tourism companies are socio-environmentally responsible. Environmental aspects and adaptation to change through innovation have the greatest weight in these companies' Corporate Social Responsibility strategies. Actions for local community development and collaboration with private agents are also important. However, human resource management influences negatively since marine tourism is a highly regulated sector in this regard. Thus, actions are mandatory and not voluntary, affecting all companies equally whether they have high levels of Corporate Social Responsibility implementation or not. Regarding relations with public authorities, the results indicate that improvement is urgently required, given the low participation of marine tourism companies in policy making.
\end{abstract}

Keywords Marine tourism · Corporate social responsibility · Governance · Islands · Sustainability

\section{Introduction}

Companies play a leading role in shifting economic models toward sustainability. Indeed, companies that integrate socially responsible strategies and actions contribute to sustainability. Likewise, public authorities can contribute their actions in collaboration with companies.

Olga González-Morales and Agustín Santana-Talavera, Member of ISTUR; David DomínguezGonzález, Researcher of ISTUR.

Olga González-Morales

olgonzal@ull.edu.es

1 Department of Applied Economics and Quantitative Methods, University of La Laguna, San Cristóbal de La Laguna, Santa Cruz de Tenerife, Spain 
In recent decades, both voluntarily and driven by public authorities, an increasing number of companies have included aspects of Corporate Social Responsibility (CSR) in their objectives and more and more companies consider the 17 Sustainable Development Goals (SDGs) to be an integral part of their competitiveness and growth strategies (Ministerio de Asuntos Exteriores, Unión Europea y Cooperación, 2018). Companies are beginning to understand that a responsible business can generate more sustainable profits and growth, new market opportunities and long-term value for all stakeholders (European Commission 2019a, b).

Business activities produce positive and negative externalities that generate both benefits and costs. CSR has become a highly effective option to minimize the negative impacts of business activities and generate shared value for the company, stakeholders and society at large (Kang et al. 2010). However, business decisions are conditioned by factors within the company's environment of an economic, social, environmental, technological and political-legal nature.

Political-legal factors stand out as key elements that are dependent on government decisions on economic policy. Governments set goals that they seek to achieve through regulatory reform, and fiscal and monetary instruments. These actions can facilitate, but also hinder business performance (González-Morales et al. 2018). However, the globalization process itself means public institutions are less able to control markets and economic activities, and thus, it is the markets that promote private initiatives of self-regulation. Within this self-regulatory framework, public institutions can endorse established rules or play a more active role, including as a mediator of conflicts. According to Fox et al. (2002), the functions that the public sector can adopt to exercise that influence can include more or less coercive actions. Basically, the public sector can adopt four approaches: to compel or regulate (mandating), to facilitate or encourage (facilitating), to collaborate or to ally (partnering) and to endorse or promote.

In the tourism sector, CSR is becoming more and more embedded. The prosperity of the sector depends directly on the state of the ecosystems in which it carries out its activities, the services it provides, new management methods by creating instruments for intergovernmental cooperation, and networks in which both public and private actors participate in decision making. This situation is particularly important in island territories with a developed tourism sector, and where sustainability strategies are used to mitigate the impact that tourism has on island ecosystems (Fernandes and Pinho 2017; Ismeri Europe and ITD.EU 2011; Manente et al. 2014; Polido et al. 2014; Weaver 2017).

This article focuses on marine tourism companies in an island territory. The main objectives are to analyze whether these companies develop a CSR strategy, observe what type of actions they carry out and how these actions influence this strategy. Following the introduction, the second section summarizes the conceptual framework. The third section sets out the hypotheses, detailing the quantitative and qualitative methodology used, and then, the fourth section includes the most relevant results derived from the empirical part. Finally, the discussion and conclusions are presented.

\section{Conceptual framework}

The tourism sector is aware that its companies must formalize a CSR strategy that contributes to achieving the objectives of sustainable development. On the one hand, tourism can cause, directly or indirectly, significant negative impacts on biodiversity and the natural environment that can lead to ecosystem degradation (habitat loss due to the development 
of tourist facilities, damage to habitats caused by tourist activities, high use of non-renewable energy and water resources, and the consequent difficulty of eliminating solid and liquid waste from accommodation, bars and restaurants, for example). On the other hand, it has been shown that tourism can contribute positively to environmental conservation and provide economic incentives to governments and communities to protect biodiversity and nature, which attracts tourists. Additionally, tourism can offer quality services in ecosystems, raise awareness about biodiversity and conservation among tourists and develop conservation support activities (WEF 2019).

Although hotel companies carry out key activities within tourist destinations and their extensive role in the application of CSR policies, there are other complementary activities with a relevant role. An example of these activities, especially important in tourist destinations, are those focused on coastal and marine tourism activities. Recognizing that coastal and marine tourism activities occupy a notable part of the tourist experience and that they can exert strong pressure on the natural and social environment, there are strong regulation and standardization of such activities. In the high consumption of these activities and services lies the interest in raising awareness of responsible water and energy use, promoting sensible consumption and offering sustainable services, in addition to managing its human resources, especially in the areas of training and prevention of occupational risks. In short, it is considered that the responsible behavior of marine tourism companies contributes to sustainable development and quality employment, with repercussions on the development and cycle of tourist destinations.

Moreover, changes in international tourist consumption models together with the sector's high competitiveness have driven the search for leisure activities to fill tourists' time in destinations. The attractiveness of coastal territories, especially insular ones, has also promoted an exponential growth of companies dedicated to marine tourism activities. These companies contribute to employment on islands and have a substantial socio-environmental impact, thus making it necessary to address a significant aspect of their activity: how the land-sea relationship can develop to achieve sustainability on islands (Grydehøj 2019). This study is focused on analyzing the actions that marine tourism companies carry out in relation to CSR, and to check whether there is a transversal, holistic and collaborative strategy among public and private agents

Hall (2001), from a macro perspective, proposes a definition of coastal and marine tourism as one that encompasses the full range of tourism, leisure and recreational activities that take place in the coastal zone and on the high seas. As a segment of this, the concept of marine tourism focuses its interest on "those recreational activities that involve traveling far from the place of residence and have as their receiver or focus the marine environment, which is defined as "those waters that are saline and are affected by the tide" (Orams 1999: 9). This wide amalgam of tourist-recreational activities includes those that use boats-also known as nautical tourism (Lukovic 2007), as well as sports activities and activities carried out on beaches and in the marine natural environment such as walking, photography, relaxing or buying products for use in the marine space in specialized stores (Orams 1999).

Summarizing, the activities that comprise marine tourism include (ECORYS 2013):

- Maritime tourism developed mainly on the water and not on land (boating, yachting, cruising, water sports, etc.) and includes the operation of land-based facilities, equipment manufacturing and necessary services.

- Coastal tourism that is represented by recreation and tourism on beaches (swimming, surfing, sunbathing, etc.), and land tourism not related to the beach in the coastal area 
(all other tourism and recreational activities that take place in the coastal zone, with proximity to the sea being a requirement), as well as supplies and manufacturing industries associated with these activities.

According to Tonazzinni et al. (2019), if island tourism is analyzed, some peculiarities that do not exist in other territories are observed. Islands are highly dependent on marine resources and the activities of the blue economy. In addition, with the unquestionable growth that marine tourism generates in destination economies, it also causes a range of environmental impacts that can lead to the deterioration of coastal and marine ecosystems (Bires and Raj 2020; Hawkins and Roberts 1994; Kurniawan et al. 2016; Miller and Auyong 1991; Miller and Ditton 1986; Pascoe et al. 2014; Romeril 1988; Wong 1993). The challenge of tourism in coastal territories is to find, through strategies and management mechanisms, a balanced adjustment between economic, environmental and sociocultural dimensions (Budowski 1976; Hall 2011; Jones 2019; Liu et al. 2020; Merli et al. 2019; Orams 1999; Papageorgiou 2016) in tourism sustainability (Bramwell and Lane 2011; Gkoumas 2019; Grilli et al. 2021; Pham 2020; Rocha et al. 2020).

In this context, governance becomes important, understood as shared management between public and private agents of socioeconomic and environmental problems. Due to its concentrated nature in specific coastal areas and its high degree of multisectoral diversification in products, marine tourism requires collaboration between public institutions, organizations and individuals (Kelly et al. 2012; Li et al. 2016), favoring the taking of informed and responsible decisions in both planning and management and in relation to the environment and the populations involved.

In an internationally agreed attempt to develop governance policies around maritimecoastal areas, the European Union's Blue Growth Strategy [COM (2012) 494] articulates the challenges regarding the EU's marine environment for Horizon 2020. With a clear integration trend, it recognizes the value of the seas and oceans as driving forces of the European economy and their potential for innovation, growth and job creation. In this framework, tourist activity associated with coasts and seas holds a relevant position. The communication from the European Union Commission "A European strategy for greater growth and employment in coastal and maritime tourism" [COM (2014) 86] proposes specific policies to develop and promote economic growth in tourism based on sustainable precepts. The commission identifies tourism as the largest maritime activity in the union, which represents more than a third of the maritime economy, provides employment for almost 3.2 million people and generates a total of 183,000 million euros of gross added value (ECORYS 2013, 2016, 2020). As evidenced by the European Commission in the communication called "A renewed and stronger strategic partnership with the outermost regions of the European Union" [COM (2017) 623], in the archipelagic regions belonging to the union, the sustainability of coastal and marine tourism is one of the great challenges to come.

In island tourist destinations, the need to establish a viable balance between economic, sociocultural and environmental impacts of tourism is more evident (Graci and Doods 2010). Specific issues concerning island ecosystems such as resource scarcity, isolation, vulnerability to natural disasters, dependence on the exterior, high concentration of endemism, demographic fluctuation through emigration-immigration cycles (Martín de la Rosa 2009), among others, are strong determining factors in sustainable tourism development in these territories. In this scenario, the environmental impacts derived from tourist activity, such as increased pressure on land use and high population density, air and water pollution, waste generation in limited spaces and the transformation of 
the natural coastal and marine environment require specific management so that, in the long term, island tourism does not end up destroying itself (Hall 2011). In this respect, public authorities play a fundamental role, as they are responsible for the development of planning strategies, management and monitoring tourist activity, and market incentives that allow the attractiveness of the destination to be maintained while preserving its natural resources (Briguglio and Briguglio 2002). Likewise, it is important to recognize the intricate interconnections that exist among government entities responsible for the environment, tourism promotion and the private sector, and the need to establish communication and joint management toward common objectives, whose goals are longterm socioeconomic and environmental sustainability (Hall 2001). In this sense, effective tourism governance, tailored to the purposes of the wide range of actors involved and specific contexts, is a key requirement to advance the objectives of sustainable tourism (Bramwell and Lane 2011; Grilli et al. 2021).

The empirical analysis for this work has been carried out on Tenerife (Canary Islands, Spain), an outermost region of the European Union located in the Atlantic and economically characterized by its high dependence on tourism.

In recent years, the Canary Island Government and other public authorities have been promoting a differentiation strategy for tourism on the islands, especially on Tenerife, which originally began as a sun and beach tourist destination. Currently, cultural, ethnographic, historical, landmarks and natural resources are valued to direct the Islands' tourist image toward a more sustainable and complementary one. In this new strategy, public-private collaboration is essential, and a coordinated decision-making process has begun, as well as the implementation of modernization plans for the destination, including those that affect marine tourism activities within a blue economy strategy.

\section{Hypotheses and methodology}

\subsection{Hypotheses}

CSR in Europe has developed as a result of the publication of the Green Paper prepared by the European Commission (2001), which defines its concept, dimensions and aspects (Table 1).

In order to analyze the degree of involvement of marine tourism companies in the development of a CSR strategy and how the actions they take influence said strategy, each of the aspects contained in Table 1 will be taken into account. Based on these aspects, the following hypotheses are proposed:

H1. Tourism companies do not have a CSR strategy; they only focus their actions on the management of environmental impact and natural resources and health and safety at work aspects, because they need to take care of the environment where they carry out their activities and control the risks associated with them.

$H 2$. The diversity of companies that this sector encompasses means that they have little strength to negotiate and cooperate with public authorities, needing inter-business cooperation to achieve public-private collaboration that allows them greater participation in decisions.

The population under study is made up of 206 establishments that carried out marine tourism activities in Tenerife in 2018, once companies involved in sunbed services were removed. The marine tourism activities in Tenerife are diverse; as examples, we can 
Table 1 Definition, dimensions, and aspects of CSR according to the European Union. Source: European Commission (2001). Prepared by authors

Definition (European Commission 2001: 6): "Most definitions of corporate social responsibility describe it as a concept whereby companies integrate social and environmental concerns in their business operations and in their interaction with their stakeholders on a voluntary basis".

Dimensions

Internal dimension and its aspects

Human resources management (job stability, training courses, equal opportunities, work/family life balance, quality of information, etc.)

Health and safety at work (optimal working conditions in terms of health and safety for workers, demands on its suppliers and business partners, responsibility toward consumers/customers, training programs, etc.)

Adaptation to change (introduction of innovations, conducting training courses that adapt to their workers/ partners and guarantee their employability, create cooperation channels with access to information, etc.)

Management of environmental impact and natural resources (environmentally friendly practices, control of resource consumption, waste, polluting emissions, continuous analysis of the impact of its services, etc.)

External dimension and its aspects

Development of local communities (acting in the local environment as a driving force in its development, contributing to the quality of life of the citizens of their community, participating in the promotion of local culture and traditions, etc.)

Collaboration with business partners, suppliers and consumers (select suppliers that respect the environment, human resources, etc.)

Linked to human rights (adoption of codes of conduct, compliance with international human rights declarations, etc.)

Helping to solve some global ecological problems (measuring the impact of business activities on the environment and the role of the company in sustainable development, carrying out cooperative actions with other countries, public administrations and other companies that contribute to a partner environment that is environmentally sustainable, etc.)

mention surfing, scuba diving, sailing, coastal activities, as well as coastal resources and specialized shops.

Two types of methodology were used to obtain information: quantitative and qualitative.

\subsection{Quantitative methodology}

To collect information from these companies, an ad hoc questionnaire was prepared with questions based on the Ethos Institute (2019) indicators on CSR, harmonized with the ISO 26000 guidelines and the G4 standards of the Global Reporting Initiative (GRI 2014).

As already mentioned, the questionnaire was structured considering the indications of the European Commission (2001). The type of activity carried out by these companies' influences their size, and they are mostly small companies. It was decided to group the aspects of Table 1 into five factors, as shown in Table 2.

The structure and content of the questionnaire, as well as the overall percentages of each item, are given in "Appendix 1." The questionnaire is addressed to those in charge of the companies (owners and/or managers) and was completed in the second semester of 2019. The questions are answered on a Likert scale measured from 1 to 5 . The higher the score 


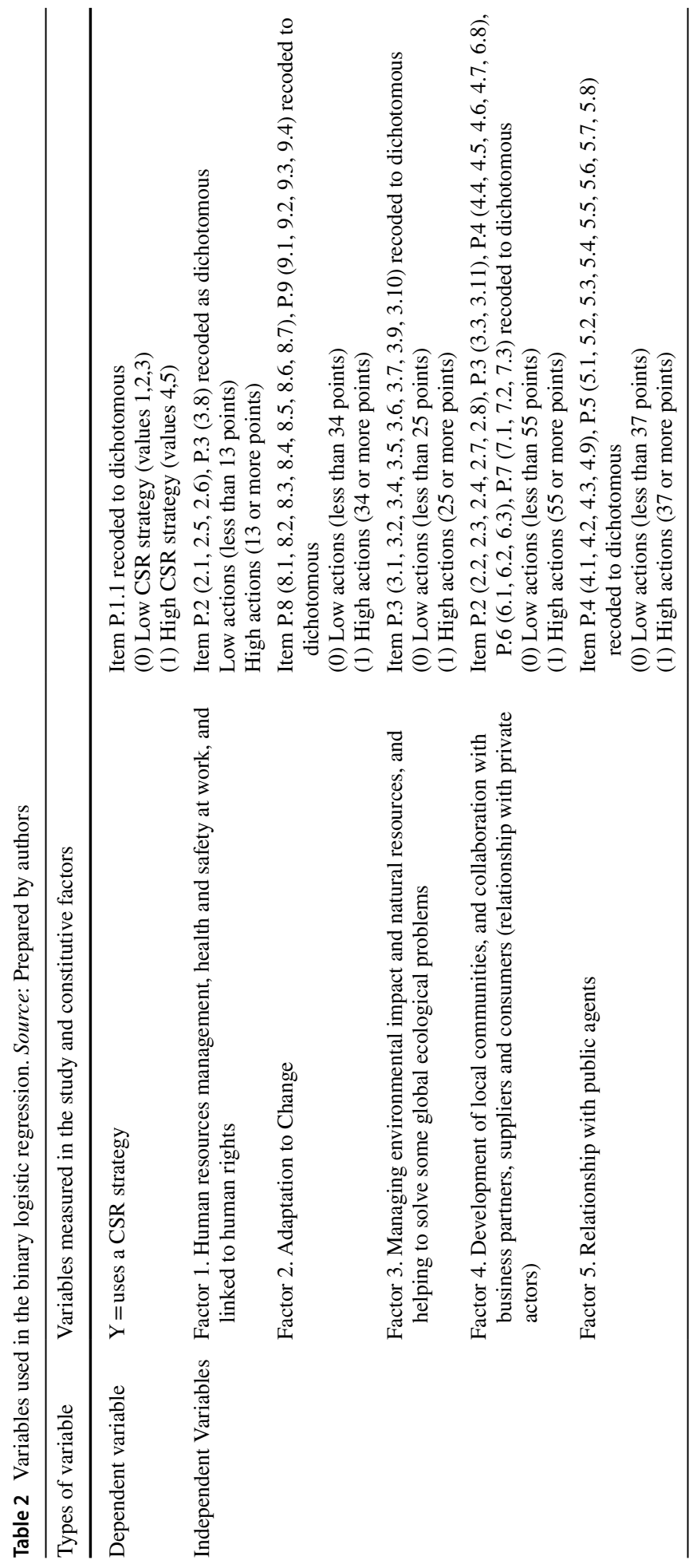


for each item, the more favorable to the question the answer is and vice versa. Out of the companies that responded $84.4 \%$ of the companies were micro-companies, $48.3 \%$ family companies and $51.7 \%$ were less than 10 years old.

Based on the stated objective and considering previous theoretical approaches, and the data obtained, it was decided to apply a binary logistic regression (BLR) analysis. Other developments of the classical linear regression model, enhanced with factor analysis, have led toward the estimation of structural equation models (Berk et al. 2010), which have been used in studies on CSR impacts (Boccia and Sarnacchiaro 2018). In this study, it was decided to use BLR because the objective of this statistical technique is to check hypotheses or causal relationships when the dependent variable is nominal. In general, logistic regression is adequate when the dependent variable $\mathrm{Y}$ is polytomous, that is, it supports several response categories, but it is especially useful, when there are only two possible responses, that is, the dependent variable $\mathrm{Y}$ is dichotomous, as is the case in this analysis.

The binary logistic regression (BLR) aims to find the best model to explain the relationship between a dependent variable (binary) and a set of explanatory independent variables (binary). The model quantifies the importance of the relationship between the independent variables and the dependent variable, as well as classifying individuals within the categories of the dependent variable Y, according to the probability of belonging to one of them depending on the presence of the independent variables (Martínez Arias 1999). Likewise, this type of statistical analysis has demonstrated its usefulness when the sample size is small (Ferreres et al. 2000; Menard 2010). Furthermore, in previous studies, authors have applied this statistical technique to the tourist accommodation and construction sectors with the same objective of analyzing CSR strategies. This will allow better comparison with the results from future studies.

The nature of the items in the questionnaire, constructed on a Likert scale, requires a transformation of the responses so that they can be used in the BLR in a dichotomous way. Therefore, the dependent variable and the independent variables became factors that measure an overall result for each group of responses, taking value 0 when it is below the mean and value 1 if it is above the mean, as observed in Table 2. The program used is SPSS 21.

The model proposed is:

$\mathrm{Y}=\operatorname{pro}\{$ yes $\}=\frac{1}{1+e^{-z}}$, where $\mathrm{Z}$ is the following linear combination

$$
Z=b_{0}+b_{1} X_{1}+b_{2} X_{2}+b_{3} X_{3}+b_{4} X_{4}+b_{5} X_{5}+\varepsilon
$$

$\mathrm{Y}=$ probability of occurrence of the event (high level of CSR), dependent variable; X1, $\mathrm{X} 2, \mathrm{X} 3, \mathrm{X} 4, \mathrm{X} 5=$ scores of the independent variables (factors 1, 2, 3, 4, 5); b0 = constant $b_{1}, b_{2}, b_{3}, b_{4}, b_{5}=$ estimated regression coefficients that inform how much the probability of $\mathrm{Z}$ occurring in the event of a unit change of each independent variable, keeping the others constant, and $\varepsilon=$ estimation error.

The Enter method was used, which uses all the variables in a single step. The omnibus test is less than 0.05 , which indicates that the factors used as independent variables explain the degree of involvement of companies in terms of CSR (dependent variable). The part of the variance of the dependent variable explained by the model ranges from $26.7 \%(0.267$ R-squared by Cox and Snell) to 39.9\% (0.399 R-squared by Nagelkerke). The Hosmer and Lemeshow test is expected to be insignificant, so that there are no significant differences between the observed and expected values; in this case, it was not significant (0.800). 
Furthermore, the model is accepted because it correctly classifies $84.5 \%$ of the companies, so the independent variables are good predictors of the dependent variable.

\subsection{Qualitative methodology}

To complement the results obtained with the quantitative methodology, a qualitative methodology was used to explore, investigate and analyze the perception of those in charge of marine tourism companies on the different aspects that make up CSR. Case study was used as a research methodology. Through this methodology, relevant information was obtained from the heads of six companies in the sector (Table 3), which allowed: (1) interaction with the informant in a natural, non-intrusive way, seeking their perspective on the issue raised, and (2) interview in depth with key informants on the most relevant aspects of CSR. With this methodology, the aim is to capture the reality of the context from the informants' perceptions (Bonilla-Castro and Rodríguez Sehk 1997) and compare it with the responses obtained in the quantitative part of the analysis.

To obtain the maximum information, the in-depth interview was used with the objective that each interviewee could freely express their opinions and beliefs, delving much deeper than a superficial response would be (Miquel et al. 1996). The interview focused on how they perceived the actions related to the five factors used in the quantitative methodology. The dimensions of information and the questions asked in the interview are given in Table 4.

\section{Results}

The descriptive results coincide with the results of the BLR model, which indicates a strong relationship between CSR strategy and factors 2 and 3, with factor 3 having the most decisive influence (Table 5). Therefore, the hypotheses proposed are fulfilled.

The descriptive results can be consulted in a disaggregated form, in percentages, in "Appendix 1". Regarding the model, Exp (b) indicates the strength of the relationship between the dependent variable and the independent variables; the further from 1 , the stronger the relationship is. To compare the exponentials of $b$ with each other, those

Table 3 Dimensions of information and informants interviewed. Source: Prepared by authors

\begin{tabular}{ll}
\hline Informants & Activity \\
\hline (E1) & $\begin{array}{c}\text { Marina. Nautical excursions. Multi-activity tours: Jet Ski, Snorkeling, Stand Up Paddle (SUP) } \\
\text { or Paddle Surf }\end{array}$ \\
(E2) & Diving Centre \\
(E3) & $\begin{array}{l}\text { Official school of surfing and its different disciplines. Sports experiences: Surfing, Bodyboard- } \\
\text { ing, SUP, Longboarding }\end{array}$ \\
(E4) & Surf and Kitesurf Center \\
(E5) & Windsurfing Center: Windsurfing, Surfing, SUP, Bodyboarding. In the winter it offers high- \\
(E6) & Whale and Dlalom equipment with racing sails
\end{tabular}


Table 4 Dimensions of the information and questions of the semi-structured interview. Source: Prepared by authors

Dimensions Questions

Strategy Do you think it is difficult to commit to a CSR strategy? What difficulties do you think you would encounter in integrating it into the company's objectives? What aspects of CSR do you think are most important?

Do you think that a small company has more difficulties to be socially responsible? Do you think that the size of the company influences when integrating CSR into business objectives?

Does the age of the company condition having a CSR strategy? Are companies that have been in the market for a short time more open to taking CSR actions? In what sense?

Factor 1 In terms of managing your human resources, do you monitor and evaluate your results? Do the workers in your company require specific and/or general training? What type?

Are your activities considered risky? Do your workers know the occupational risk plan? And your clients too?

Factor 2 Does the company adapt to changes in its environment?

Does the company innovate by introducing new products/services for its clients or improving existing ones to adapt them to the needs of clients and the community where it operates? What does it depend on?

Factor 3 Do you think that the activities carried out by your company have an impact, both positive and negative, on your nearby environment? What actions does your company take? What actions would you highlight?

Factor 4 What does your company contribute to the local community?

What relationship do you have with your suppliers, customers and other companies?

Factor 5 Is your company related in any way to public authorities (Island Council, Town Hall, Canary Islands Government, Coasts, etc.)? Is your collaboration high?

What kind of actions would you ask public authorities to implement to improve the activity of your company?

Does your company belong to an association? If yes, what type?

Do you know the Canary Island Network of CSR?

Table 5 Model proposed. Results of the binary logistic regression analysis (variables in the equation)

\begin{tabular}{|c|c|c|c|c|c|c|c|c|c|}
\hline & & \multirow[t]{2}{*}{ B } & \multirow[t]{2}{*}{ E.T. } & \multirow[t]{2}{*}{ Wald } & \multirow[t]{2}{*}{$\mathrm{gl}$} & \multirow[t]{2}{*}{ Sig. } & \multirow[t]{2}{*}{$\operatorname{Exp}(B)$} & \multicolumn{2}{|c|}{$\begin{array}{l}\text { I.C. } 95.0 \% \text { for } \\
\operatorname{EXP(B)}\end{array}$} \\
\hline & & & & & & & & Inferior & Superior \\
\hline \multirow[t]{6}{*}{ Step 1(a) } & FAC_1 & -.147 & 1.325 & .012 & 1 & .912 & .863 & .064 & 11.594 \\
\hline & FAC_2 & 1.642 & .774 & 4.497 & 1 & .034 & 5.167 & 1.132 & 23.572 \\
\hline & FAC_3 & 2.115 & 1.108 & 3.641 & 1 & .056 & 8.289 & .944 & 72.769 \\
\hline & FAC_4 & 1.124 & .874 & 1.654 & 1 & .198 & 3.076 & .555 & 17.052 \\
\hline & FAC_5 & -.487 & .920 & .280 & 1 & .596 & .614 & .101 & 3.730 \\
\hline & Constant & -1.892 & 1.242 & 2.320 & 1 & .128 & .151 & & \\
\hline
\end{tabular}

${ }^{\text {a }}$ Variable(s) introduced(s) by steps 1: FAC_1, FAC_2, FAC_3, FAC_4, FAC_5 
that are less than 1 must be transformed into their inverse or reciprocal, that is, 1 must be divided by $\operatorname{Exp}(\mathrm{b})$.

The factors that contribute the most to the development of a true CSR strategy are the environmental aspect accompanied by aspects of adaptation to change, which implies that companies innovate and train their personnel to adapt to innovations. Although the remaining factors are not significant, it is interesting to observe them from the point of view of their contribution to the CSR strategy. Actions carried out for the development of local communities and collaboration with private agents have a high positive score (factor 4). However, actions in human resource management (factor 1) and the relationship with public agents (factor 5) are negative, which indicates that they contribute negatively, reducing the probability of having a true CSR strategy, which deserves a more detailed explanation.

Companies with CSR strategies integrated into their objectives carry out more than average socially responsible actions in all factors when compared to those companies that do not have a CSR strategy. The case of relations with public agents is relevant due to the low scores on the items analyzed, although they continue to be higher in companies with socially responsible strategies ("Appendix 2").

The outcomes of the interviews support these results ("Appendix 3"). All the companies interviewed carry out CSR actions but do not include them in any written document. In the words of informant E4

I think that a little common sense and respect for the environment comes naturally to us, at the moment, we have not thought of writing it anywhere because we all are very responsible.

It fundamentally highlights the enormous respect for the environment that everyone manifests. Thus, E1 indicates that "We are aware of all the impacts that our activity generates on everything that is the environment, of course, and on everything that is called a stakeholder in a company... the fundamental strategy is to achieve... that the attributes of the destination go with the sustainability". E2 focuses the impacts of its activity mainly on the anchors needed to anchor ships to the seabed, commenting that problems like this that could be improved to reduce the impact on the seabed if, for example, municipalities collaborate with companies by setting fixed anchorages.

This attitude sensitizes companies toward caring for their environment and to seek innovations to improve their products and services. One of the actions that are repeated among the companies interviewed is the recycling of obsolete products through collaboration with other companies in the area, especially those dedicated to the same sector or to crafts.

Although business size does not appear to be an impediment to acting in a socio-environmentally responsible way, they understand that small businesses sometimes cannot face certain challenges and are stifled by public actions. In E6's opinion, integrating CSR into the company's objectives

... when there are values behind it, I do not see it as difficult and we even donate for charitable purposes, and we want to start projects aimed at people in social exclusion, that is, that, no matter how small the company, you can always do something, especially a small company which has an entrepreneur, by the mere fact of having a small company, gets more involved... the small company has that driving force of needing to improve in order to survive, and so I think that this can do a lot socially. 
The most important problem mentioned is the obstacles derived from excessive regulation or lack of coordination among different public authorities. They ask the authorities to control the intrusion into their activity and to reduce taxes and administrative obstacles. Having few relations with public administrations beyond those derived from the mandatory regulations, they consider that the collaboration between companies in the sector could help to improve relations. E2 indicates that they are trying to form an association, as a valid interlocutor, to have more strength when dealing with public authorities.

\section{Discussion and conclusions}

This work has analyzed the weight that each of the aspects that make up CSR has in the strategies of marine tourism companies.

Two hypotheses were proposed. Hypothesis 1 stated that marine tourism companies do not have a CSR strategy, but they only develop aspects regarding the management of environmental impacts and natural resources and health and safety at work. Human resource management is a very important issue for marine tourism companies, not only in terms of training and working conditions, but, above all, in terms of occupational health and safety, given the risks that many of these activities entail, so it would be advisable to increase actions in this regard. The same applies to environmental aspects, since these companies depend on the environment to carry out their activities and need it to be as attractive and well preserved as possible.

Our results partially support this hypothesis. On the one hand, the environmental aspect is the one that contributes the most to marine tourism companies' CSR strategies and supports their contributions to goals 13 and 14 of the SDGs. Although, as Higgins-Desbiolles (2018) indicate, in island territories the environmental criteria integrated into the legal obligations of companies are demanding, in the case of marine tourism companies, these contribute to the island's sustainability beyond their strictly legal obligations. On the other hand, it is paradoxical that there is a low contribution of health and safety at work, with this area even having a negative impact on contributions to CSR. This is explained by the high number of mandatory regulations that homogenizes the behavior of all companies, whether or not they are socio-environmentally responsible, leaving little room for nonmandatory actions.

However, adaptation to change, reflected in the innovations that the sector has introduced in recent years, is an aspect with great influence on CSR strategies. This aspect, so common in the tourism system, has shown its importance in improving the competitiveness of the sector, differentiating processes, products and services. For companies with highly strategic CSR, innovation by organizing more efficient processes with fewer environmental impacts is a way to contribute to sustainable development.

Likewise, the group of companies offering coastal and marine tourism products see themselves as the main actors for successful social sustainability of a tourist destination. The study shows that these companies have an important role within their community and commitment to their partners, suppliers, customers and other related companies, although with some difficulties. 
Basically, it is the relations with public authorities that have the worst evaluations and the greatest negative impact. In this sense, González-Morales et al. (2018) already indicated that government action can facilitate but can also hinder business performance. In this case, companies in the sector perceive the public administration as a hindrance to their actions, largely due to the lack of dialog and collaboration between parties. This result indicates that hypothesis 2 has been fulfilled. The diversity of companies that encompasses the marine tourism sector means that they have little strength when it comes to negotiating and cooperating with public authorities, needing inter-business cooperation to achieve greater public-private collaboration and greater participation in decision making. As indicated, marine tourism is a set of business activities with an important, varied and detailed regulation from different public authorities (from the European level to the local level, through the State Administration, Autonomous Regional Governments and the Island Governments). There are no accessible communication channels, blurring the relations that should lead to an effective governance structure. The response has come from the companies themselves, promoting the constitution of two associations, one specifically for marine tourism and the other for active tourism, which aim to give a common voice and have weight in decision making. Internal governance is manifested as a procedure to be taken into account when planning and in innovative proposals aimed at promoting CSR. This is in line with Massukado and Teixeira (2007), who considered that companies have a positive attitude toward public-private cooperation that is identified with association, a common goal and teamwork.

It is considered that the small business character of marine tourism can contribute to CSR to a large extent, because it promotes an improved distribution of the socioeconomic benefits that tourism brings to the island (SDG 8 and 10). However, this same characteristic shows a fragmented sector with barriers to collaboration and the exchange of knowledge and good practices. In this study, the results indicate that business size does not seem to be an obstacle to contributing to the sustainable development of the island through CSR actions, which is in line with Blombäck and Wigren (2009). They consider that it is local integration and companies' individual motivation that explains if a company is socio-environmentally responsible and not its business size.

It has been verified that the activities carried out by marine tourism companies add value and quality to the tourism experience and provide an important diversification of the complementary offer in a destination that, despite offering other types of tourism, looks out on the sea continually. However, sometimes, the important role these companies play in the island's tourism system is not recognized. Added to this is the lack of a clear definition that defines and allows the development of indicators on coastal and marine tourism. This generates weaknesses and fewer appropriate responses and measures. This point is one of the limitations of the study due to the great diversity of activities that make up this sector, with different problems. This study presents the most general and common results for the sector, complemented by in-depth interviews, that has obtained a broad view of certain activities, whose impact on the island is important, though has not included all the activities classified within the group of marine tourism. This requires further research into new issues in the future.

Based on the strength of the data, the coastal and marine tourism sector has been included as one of the five fundamental axes of the European Union's "European Blue Growth Strategy," whose purpose is based on the assumption that the marine economy 
is one of the economic growth engines of the member states in the coming decades. This compendium of public policies tries to observe coastal and marine tourism as an area with special potential to promote an intelligent, sustainable and inclusive Europe.

In line with this, in the Canary Islands, blue growth is included as a priority in the Intelligent Specialization Strategy 2014-2020 (RIS3), focusing on productive diversification based on innovation, technological renewal and sustainability (https://www3.gobiernode canarias.org/aciisi/ris3/strategy-ris3-anarias/summary). But the strategy has not yet been carried out, though the need for it is shown in this study. Such a strategy should provide well-designed regulations, laws by listening to and learning about the problems faced by companies in the sector, solve the lack of coordination between public authorities that leads to increased bureaucracy or collision of regulations, provide support through technical assistance, training and information and create incentives of various kinds.

This has been the first attempt to study the CSR actions carried out by the marine tourism sector on the island of Tenerife. The results are expected to help the public authorities and institutions involved to better understand the current challenges of marine tourism companies, establishing their priorities through comprehensive and coherent regulations of marine tourism activities, so that these companies can increase their contributions to the global objectives of sustainable development.

Recognizing the importance of the CRS in Blue Growth and its implications in the requalification and adaptation of business models, the research team is aware that the Tourist System shows differential elements in each of the islands of the archipelago. The current research project poses as a task the comparison of these and the establishment of recommendations. However, the time of the COVID-19 is showing limitations (zero tourism, resilience and reorganization) and raises a possible organizational reconfiguration of marine tourism. Future research may offer different patterns than the current ones, but it is also possible that they force a conceptual review of the tourism system itself.

Acknowledgements This article is the result of research work carried out within the project Tourist Intelligence for Responsible Marine Tourism (INTURMAR) project, led by Dr. Agustín Santana Talavera of the University of La Laguna. This work was supported by the Smart Specialization Strategy of the Canary Islands RIS-3 co-financed by the Operational Program FEDER Canarias 2014-2020 under Grant ProID2017010128.

\section{Compliance with ethical standards}

Conflict of interest The authors have not reported any potential conflict of interest in relation to this article.

\section{Appendix 1}

See Table 6. 


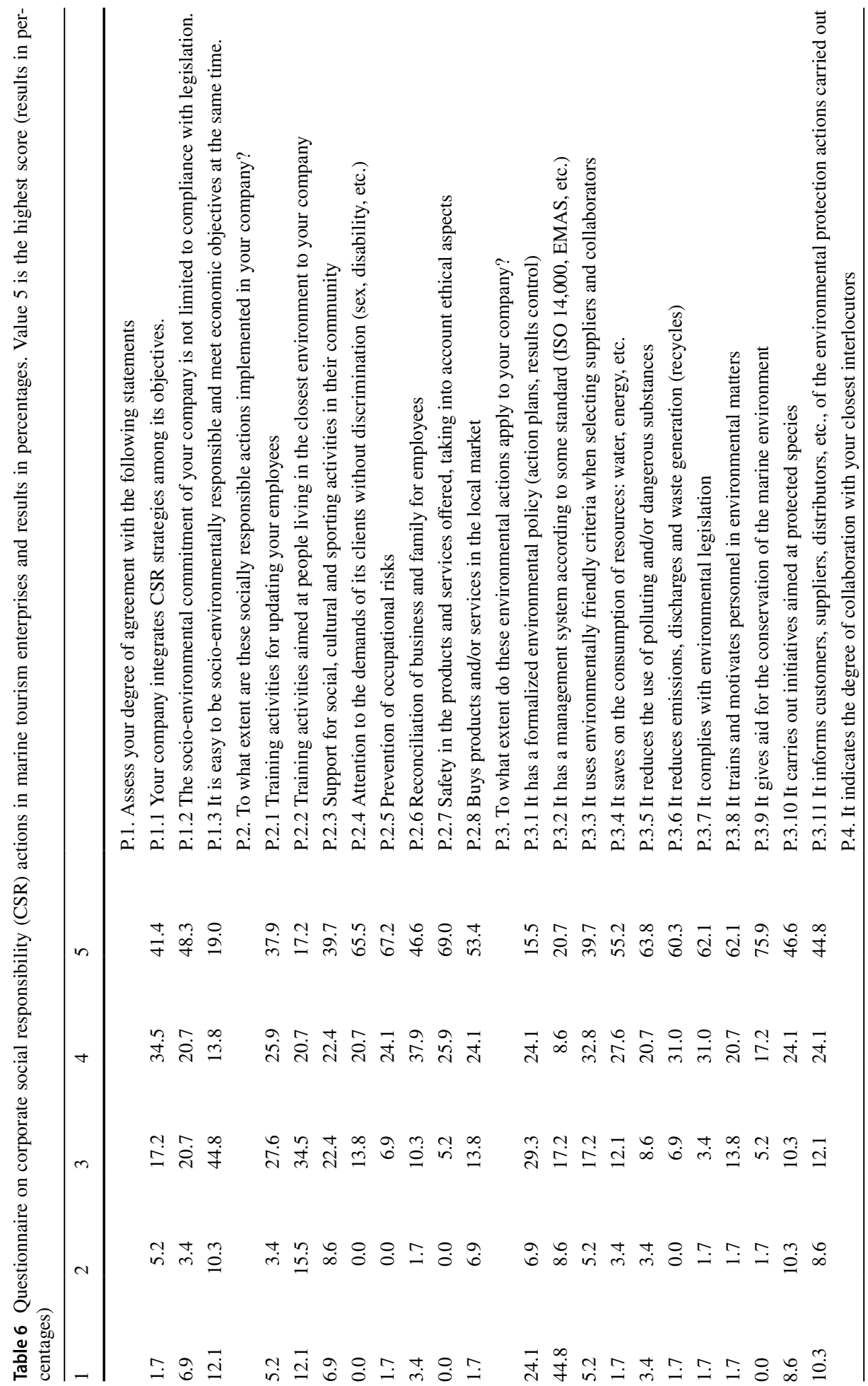




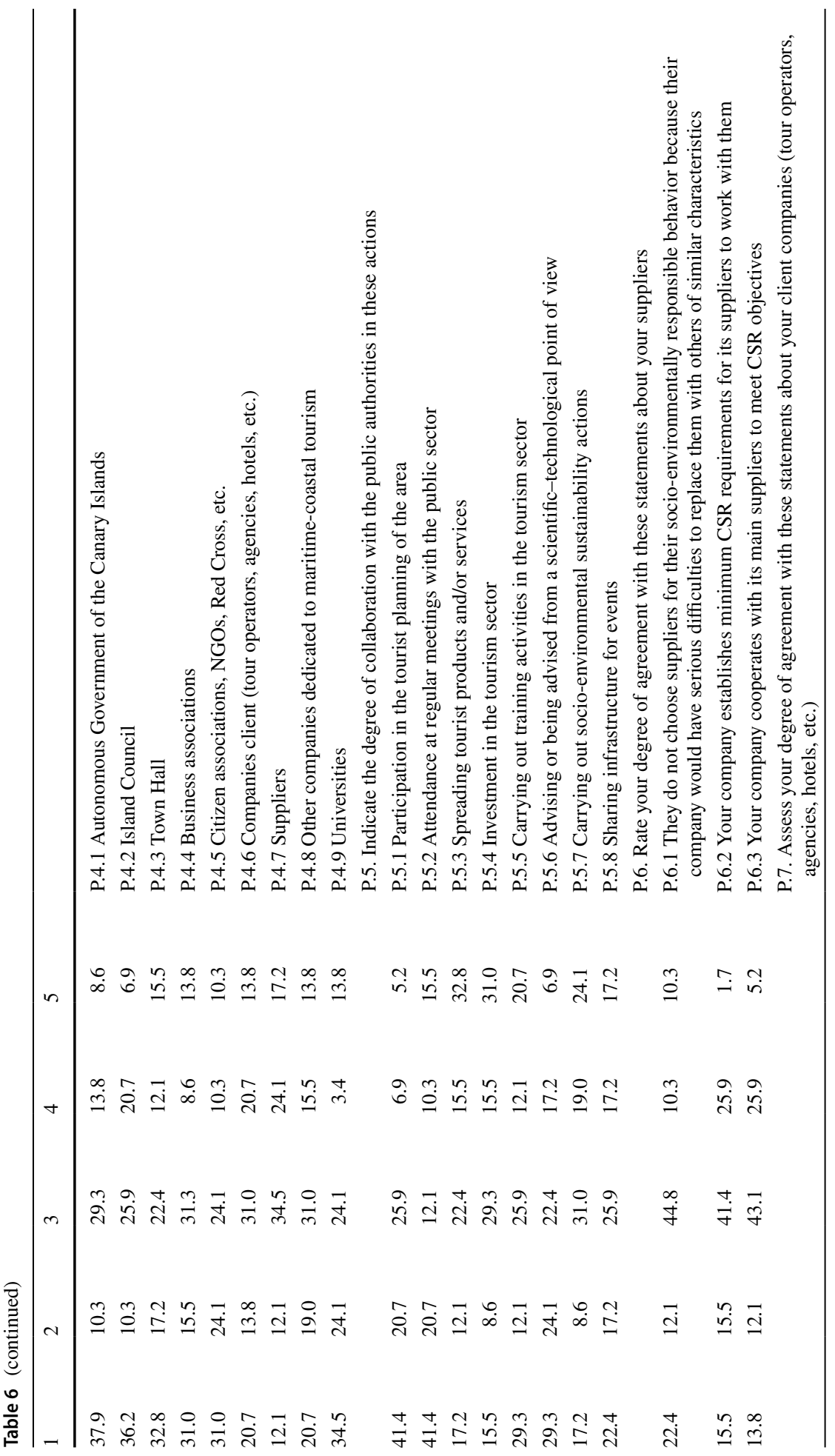




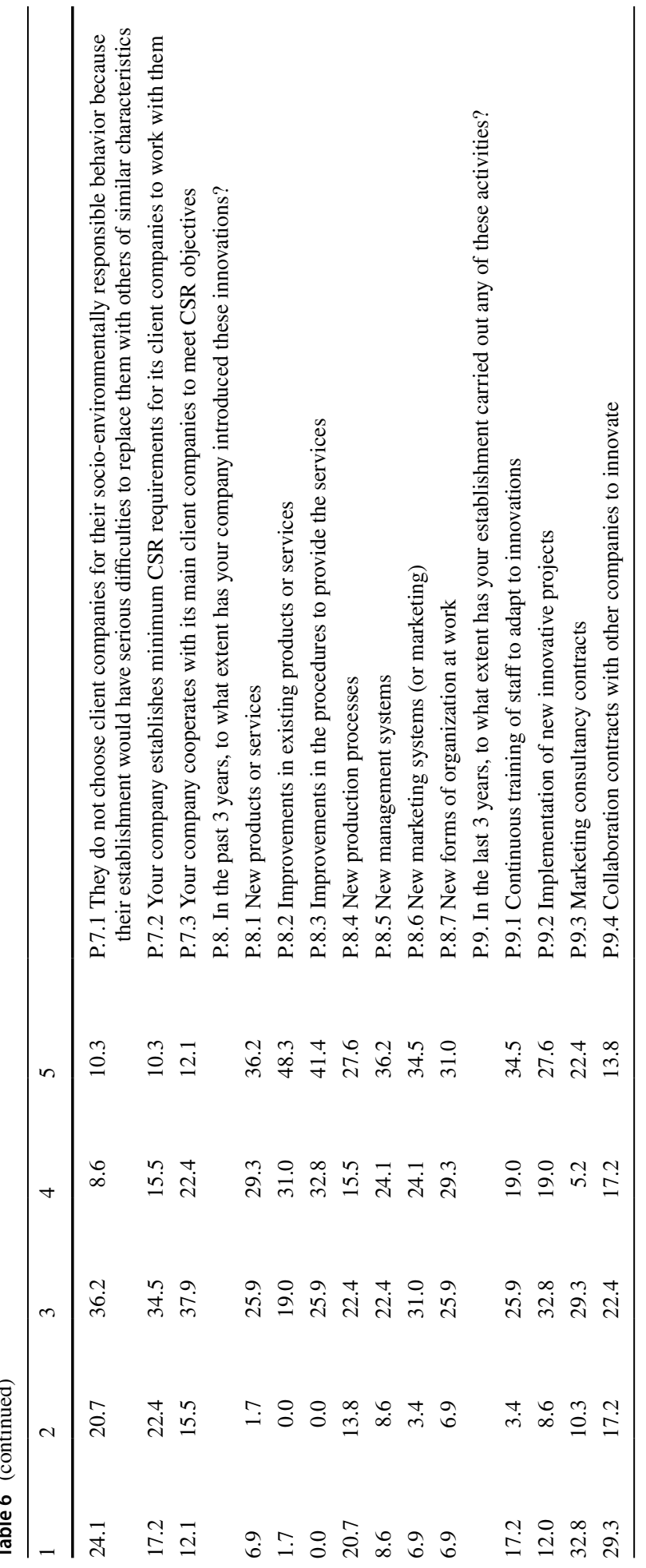




\section{Appendix 2}

\section{See Table 7.}

Table 7 Contingency table between the degree of CSR commitment according to the companies and the different factors that encompass CSR actions (in percentage)

\begin{tabular}{llll}
\hline Factors & \multicolumn{2}{l}{$\begin{array}{l}\text { CSR strategies integrated in the } \\
\text { objectives of the company }\end{array}$} & Chi squared \\
\hline Factor 1. Human resources management & Low & High & Significant at 10\% \\
Below-average actions & 21.4 & 4.5 & \\
Above-average actions & 78.6 & 95.5 & Significant at 5\% \\
Factor 2. Adaptation to change & Low & High & \\
Below-average actions & 71.4 & 25.0 & Significant at 5\% \\
Above-average actions & 28.6 & 75.0 & \\
Factor 3. Environmental actions & Low & High & \\
Below-average actions & 42.9 & 4.5 & Significant at 5\% \\
Above-average actions & 57.1 & 95.5 & \\
Factor 4. Local community development and & Low & High & \\
engagement with business partners & & & \\
Below-average actions & 57.1 & 20.5 & Nonsignificant \\
Above-average actions & 42.9 & 79.5 & \\
Factor 5. Relationship with public agents & Low & High & \\
Below-average actions & 78.6 & 63.6 & \\
Above-average actions & 21.4 & 36.4 &
\end{tabular}




\section{Appendix 3}

See Table 8 .

Table 8 Summary of informants' responses

Informants Summary of the most notable responses

CSR Strategy

Factor 1

Human Resources
The six informants indicate that they carry out a CSR strategy; they meet in their respective companies to improve all aspects. It is not a formalized written strategy, but it is applied. Customers perceive it positively

Do you think that the size of the company influences when integrating CSR into business objectives?

E1. I do not know

E2. A small company, even a single company within the sector, cannot do anything, they can take actions individually but cannot change things. The smaller, the less you can do

E3. Yes, a company with greater capacity also has greater facility to implement CSR actions

E4. No, that is not an excuse to carry out good practices

E5. It is possible to have a CSR strategy in any type of company; it will depend on those responsible

E6. Size does not matter. We are a small company, with a high degree of introduction of innovations and a complete CSR strategy. Sometimes small businesses get more involved

Does the age of the company condition the implementation of a CSR strategy? Are companies that have been in the market for a short time more open to taking CSR actions? In what sense?

E1. The management style of young companies helps by being less hierarchi$\mathrm{cal}$ and with a more horizontal structure for decision-making

E2. No

E3. I do not know

E4. No, that is not an excuse to carry out good practices

E5. Yes, it is difficult to change the way you act when you have been in the market for a long time, it will depend on how dynamic and innovative the company is

E6. I do not see it difficult if there are values behind those responsible

The six informants indicate that their activities are risk activities (occupational risk plans), highly regulated (liability insurance of various kinds) and require training required by law (skippers, sailors, diving instructor, first aid, surf coaches, sailing technician, tourism sector guides). But they also receive other training. Some specificities are:

E1. We receive voluntary training (courses aimed at improving customer treatment, the information they must transmit and their capabilities) and, secondly, out of necessity due to the introduction of innovations in products/ services or internal operating processes

E3. We demand courses related to safety in the maritime environment, there is not a wide offer

E5. We carry out safety courses for workers and clients, although there are clients who once in the water forget

E6. We investigate cetacean issues with university scientists 
Table 8 (continued)

Informants

Factor 2

Adaptation to change (Innovation)

Factor 3

Environmental Impact

Factor 4

Local community development

Relationship with the private sector
Summary of the most notable responses

E1. Technology as a competitive advantage to improve the product, the quality and the tourist experience (integrated reservation system with automated communication between company and clients, video briefing, headphone system for communication between groups of clients and improving safety as well)

E2. Instructors of technical diving, adaptive diving. Use of social networks

E3. Marketing through social networks and other media on the Internet

E4. Introduction of new sports (Kitesurfing, Wild ford, Wind foil), new materials (kite shape, suits and lighter materials), professional slalom training. Marketing through social networks, website

E5. New methodology (Windsurfing Foiling), new sports (Bodyboarding, SUP)

E6. We have an award for innovation and leadership in responsible tourism for making positive changes in whale sightings. They introduce a multitude of innovations (hybrid ecological boat, electric motors with solar panels to minimize noise and obtain energy, ecological boat hull painting, recycling trying zero waste, on-board consumption of ecological agri-food products from local businesses, educational material in digital format, cameras integrated in the case to listen to the whales)

All informants emphasize this issue and convey their commitment, aware that it is important

E1. Weaving sustainability into the fabric of a tourist destination. We have the role of arbitrator between the port and the companies located in it. We collaborate with initiatives such as the Island Council's Sustainable Tourism Charter

E2. We request the city council to put fixed anchorages so that the impact of the anchors decreases

E3. We improve the load capacity of the spaces. Recycle expanded polyurethanes. Tables with more environmentally friendly materials

E4. We collect microplastics, nails and other waste from the beach. Recycling of waste

E5. We have a responsible consumption of water. Garbage collection and recycling. Recycling of defective materials used in sports in collaboration with local artisans

E6. The innovations outlined in Factor 2 go a long way toward improving environmental problems

E1. We develop commercial revitalization activities in the port so that it has an impact on local employment, encourages local business initiatives and attracts tourists

E2. We collaborate with other companies in the sector

E3. We revitalize the beach with a municipal school

E4. Our activities attract tourists who consume products/services in the same place (restaurants, hotels, pubs)

E5. We collaborate with associations by conducting joint studies. They inform educating tourists on the respect of marine species, involving them in the conservation of species. They investigate the stress of the cetaceans of the area 
Table 8 (continued)

Informants

Factor 5

Relations with public administrations
Summary of the most notable responses

Relations with public authorities and administrations and what they request

E1. Town Councils, Island Council, Government of the Canary Islands. The local administration (town councils) is closer and has closer relationships, but as the level rises it is more complicated. I meet with the town council to economically boost the area

I ask the public administrations to fulfill their role of regulating and enforcing the regulated, but not to over-regulate, to regulate with common sense and not to increase bureaucratization, to be open to all economic and social agents and to be able to coordinate/moderate

E2. We hardly collaborate. The closest is the Town Hall. The relationships are many, but because you have to comply with the regulations (permits, licenses). We want to collaborate with everyone (City Councils, Department of Agriculture, Livestock, Fishing and Water, Ministry of Agriculture, Food and Environment-Coasts, Harbor Master), but there is no way. They have changed the law, but we have not been consulted, there are contradictions and it does not reflect reality

We ask the Public Administrations to speak to our sector. As they don't listen to us, we are organizing to legalize an association. There is excess regulation for some things and absence of it in others. A degree is requested that, at this time, cannot be obtained in the Canary Islands. There is also no control or monitoring in compliance with the law and regulations

E3. We have a relationship with almost all the administrative body of the State: Town Councils, the Island Council, the Undersecretary of the Environment, the Coastal District. The Town Hall is the closest and with which e have the most contact. The Cabildo is the second because it resolves the transport permits. The Surfing Federation helps the collaboration because it meets many times with the Public Administrations, but there is a gap around the management of the surfing activity

The activities are developed in an administrative tangle (territorial planning, environment, tourism, sports activities, commercial activities), not very coordinated and disconnected from the sector

We ask the public authorities to organize and provide legal security. There is clear legislation but a lack of willingness to coordinate effectively

E4. Little relationship with Town Councils, Island Councils, Environment (Canary Islands Government), Coasts, only to apply for permits or make some specific regulation of the area

We ask the Public Administrations for a little more control because there are activities that are carried out without being regulated

E5. Town Hall, Island Council, Harbor Master, but mainly to apply for permits

We ask the Public Administrations to be more flexible with the restrictions. There are many gaps in the regulation that is applied and sometimes this encourages illegal activities. We should be more involved

E6. We have a high collaboration with the Canary Islands Government, carrying out pilot projects on sustainability in cetacean sighting, promoting computer applications of the Ministry of Ecological Transition and the fight against climate change. They collaborate with the Ministry of Ecological Transition. They collaborate with Universities

We ask the Public Administrations not to stifle small businesses and to help them not only with subsidies but also with lowering taxes in order to have a quality activity and to be able to generate quality jobs

Does your company belong to any association? If so, what kind?

E2. We are planning to create an association

E3. Official Network of Surfing Schools, Association of Active Tourism Entrepreneurs

E4. Not an association as such but we do hold meetings with other companies in the area

Do you know the Canary Island Network of CSR?

None of the informants knew about the Canary Island Network of CSR 


\section{References}

Berk, R., Brown, L., \& Zhao, L. (2010). Statistical inference after model selection. Journal of Quantitative Criminology, 26, 217-236.

Bires, Z., \& Raj, S. (2020). Tourism as a pathway to livelihood diversification: Evidence from biosphere reserves, Ethiopia. Tourism Management, 81, 104-159. https://doi.org/10.1016/j.tourman.2020.104159.

Blombäck, A., \& Wigren, C. (2009). Challenging the importance of size as determinant for CSR activities. Management of Environmental Quality, 20(3), 255-270. https://doi.org/10.1108/14777830910950658.

Boccia, F., \& Sarnacchiaro, P. (2018). The impact of corporate social responsibility on consumer preference: A structural equation analysis. Corporate Social Responsibility and Environmental Management, 25(2), 151-163.

Bonilla-Castro, E., \& Rodríguez Sehk, P. (1997). Más allá del dilema de los métodos. Bogotá: Grupo Editorial Norma.

Bramwell, B., \& Lane, B. (2011). Critical research on the governance of tourism and sustainability. Journal of Sustainable Tourism, 19(4-5), 411-421.

Briguglio, L., \& Briguglio, M. (2002). Sustainable tourism in small islands: the case of Malta. In F. di Castri \& V. Balaji (Eds.), Tourism, biodiversity and information (pp. 169-184). The Netherlands: Backhuys Publishers.

Budowski, G. (1976). Tourism and environmental conservation: Conflict, coexistence, or symbiosis? Environmental Conservation, 3(1), 27-31.

ECORYS. (2013). Study in support of policy measures for maritime and coastal tourism at EU level. Rotterdam/Brussels: ECORYS.

ECORYS (2016) Study on specific challenges for a sustainable development of coastal and maritime tourism in Europe. https://doi.org/10.2826/94993).

ECORYS (2020) Study on the contribution of tourism to local and regional development Evidence from the European structural and investment funds 2012-2018: Final report. https://op.europa.eu/en/publicatio n-detail/-/publication/f38cad5e-72f8-11ea-a07e-01aa75ed71a1/language-en/format-PDF/source-search

Ethos, Instituto. (2019). Indicadores Ethos para negocios sustentaveis e responsaveis. Sao Paulo (Brasil): Instituto Ethos.

European Commission. (2001). Promoting a European framework for Corporate Social Responsibility. Brussels: European Commission.

European Commission. (2012). Crecimiento azul. Oportunidades para un crecimiento marino y marítimo sostenible. COM (2012) 494 final. https://eur-lex.europa.eu/legal-content/ES/TXT/PDF/?uri=CELEX :52012DC0494\&from=ES

European Commission. (2014). A European Strategy for more Growth and Jobs in Coastal and Maritime Tourism. 20.2.2014 COM (2014) 86 final. Brussels: European Commission.

European Commission. (2017). Commission Staff working document on Nautical Tourism. 30.3.2017. SWD (2017) 126 final. Brussels: European Commission.

European Commission (2019a). Overview of EU Tourism Policy. https://ec.europa.eu/growth/sectors/touri sm/policy-overview_en.

European Commission (2019b) Reflection Paper Towards a Sustainable Europe by 2030 30.1.2019 COM (2019) 22 final. Brussels: European Commission.

Fernandes, R., \& Pinho, P. (2017). The distinctive nature of spatial development on small islands. Progress in Planning, 112, 1-18. https://doi.org/10.1016/j.progress.2015.08.001.

Ferreres, D., Fidalgo, A., \& Muñiz, J. (2000). Detección del Funcionamiento Diferencial de los ítems no uniforme: Comparación de los métodos Mantel-Haenszel y regresión logística. Psicothema, 12(2), 220-225.

Fox, T., Ward, H., \& Howard, B. (2002). Public sector roles in strenghening corporate social responsibility: A baseline study. Washington: The World Bank.

Gkoumas, A. (2019). Evaluating a standard for sustainable tourism through the lenses of local industry. Heliyon, 5(11), e02707. https://doi.org/10.1016/j.heliyon.2019.e02707.

González-Morales, O., Díaz Pérez, F.Mª , \& Peña Vázquez, R. (2018). Políticas de emprendimiento e internacionalización empresarial. In E. Aranda García, S. Pérez Moreno, \& A. Sánchez Andrés (Coords), Política Económica y Entorno Empresarial (pp. 193-222). Madrid: Pearson.

Graci, S., \& Doods, R. (2010). Sustainable tourism in island destinations. London: Earthscan.

GRI. (2014). GRI G4 Guidelines and ISO 26000:2010: How to use the GRI G4 Guidelines and ISO 26000 in conjunction. Genova/Amsterdam: ISO/GRI.

Grilli, G., et al. (2021). Prospective tourist preferences for sustainable tourism development in Small Island Developing States. Tourism Management, 82, 104178. https://doi.org/10.1016/j.tourman.2020.104178.

Grydehøj, A. (2019). Marine island economies: Drivers, roles, and challenges. In L. Brinklow, L. Liyun, \& C. Qinhong (Eds.), The 21st century maritime silk road: Islands economic cooperation forum-annual 
report on global islands 2018 (pp. 103-122). Charlottetown, Prince Edward Island, Canada: Island Studies Press at UPEI Publishers.

Hall, M. (2001). Trends in ocean and coastal tourism: The end of the last frontier? Ocean and Coastal Management, 44(9-10), 601-618.

Hall, M. (2011). Policy learning and policy failure in sustainable tourism governance: From first and second-order to third-order change. Journal of Sustainable Tourism, 19(5), 649-671.

Hawkins, J. P., \& Roberts, C. M. (1994). The growth of coastal tourism in the Red Sea: Present and future effects on coral reefs. Ambio, 23(8), 503-508.

Higgins-Desbiolles, F. (2018). Sustainable tourism: Sustaining tourism or something more? Tourism Management Perspectives, 25, 157-160.

Ismeri Europe \& ITD.EU (2011). Growth Factors in the Outermost Regions. Final Report (Vol. 1 and 2). Brussels: Ismeri Europe.

Jones, P. J. S. (2019). A governance analysis of Ningaloo and Shark Bay Marine Parks, Western Australia: Putting the 'eco' in tourism to build resilience but threatened in long-term by climate change? Marine Policy. https://doi.org/10.1016/j.marpol.2019.103636.

Kang, K. H., Lee, S., \& Huh, C. (2010). Impacts of positive and negative corporate social responsibility activities on company performance in the hospitality industry. International Journal of Hospitality Management, 29(1), 72-82.

Kelly, C., Essex, S., \& Glegg, G. (2012). Reflective practice for marine planning: A case study of marine nature-based tourism partnership. Marine Policy, 36(3), 769-781.

Kurniawan, F., et al. (2016). Vulnerability assessment of small islands to tourism: The case of the Marine Tourism Park of the Gili Matra Islands, Indonesia. Global Ecology and Conservation, 6, 308-326. https://doi.org/10.1016/j.gecco.2016.04.001.

Li, R., van der Brink, M., \& Woltjer, J. (2016). Rules for the governance of coastal and marine ecosystem services: An evaluative framework based on the IAD framework. Land Use Policy, 59, 298-309.

Liu, J., An, K., \& Jang, S. S. (2020). A model of tourists' civilized behaviors: Toward sustainable coastal tourism in China. Journal of Destination Marketing \& Management, 16, 100437. https://doi. org/10.1016/j.jdmm.2020.100437.

Lukovic, T. (2007). Nautical tourism-definitions and dilemmas. Naše more, Znanstveno-strucni casopis za more i pomorstvo, 54(1-2), 22-31.

Manente, M., Minghetti, V., \& Mingotto, E. (2014). Responsible tourism and CSR: Assessment systems for sustainable development of SMEs in tourism. Switzerland: Springer. https://doi.org/10.1007/9783-319-06308-9_2.

Martín de la Rosa, B. (2009). Turismo en ecosistemas insulares. Antropología en el paraíso. El Sauzal (Tenerife): PASOS Revista de Turismo y Patrimonio Cultural. Colección PASOS Edita, 3. http://www. pasosonline.org/Publicados/pasosoedita/PSEdita3.pdf. Accessed 20 Mai 2020.

Martínez Arias, R. (1999). El Análisis Multivariante en la Investigación Científica. Madrid, España: La Muralla/Hespérides.

Massukado, M. S., \& Teixeira, R. M. (2007). Como cooperar em turismo? Configuraçao em redes para empresas turísticas. Sâo Paulo: Anais do Seminário de ANPTUR.

Menard, S. (2010). Logistic regression. From introductory to advanced concepts and applications. Thousand Oaks, CA: Sage.

Merli, R., et al. (2019). The impact of green practices in coastal tourism: An empirical investigation on an eco-labelled beach club. International Journal of Hospitality Management, 77, 471-482. https://doi. org/10.1016/j.ijhm.2018.08.011.

Miller, M., \& Auyong, J. (1991). Coastal zone tourism: A potent force affecting environment and society. Marine Policy, 15(2), 75-99.

Miller, M., \& Ditton, R. (1986). Travel, tourism, and marine affairs. Coastal Zone Management Journal, 14(1-2), 1-18.

Ministerio de Asuntos Exteriores, Unión Europea y Cooperación (2018). Plan de Acción para la Implementación de la Agenda 2030. Hacia una Estrategia Española de Desarrollo Sostenible. Madrid: Dirección General de Políticas de Desarrollo Sostenible. Secretaría de Estado de Cooperación Internacional y para Iberoamérica y el Caribe.

Miquel, S., Bigné, E., Cuenca, A. C., Miquel, M. J., \& Lévy, J. P. (1996). Investigación de Mercados. Madrid: McGraw-Hill Interamericana.

Orams, M. (1999). Marine Tourism: Development, impacts and management. London: Routledge.

Papageorgiou, M. (2016). Coastal and marine tourism: A challenging factor in Marine Spatial Planning. Ocean and Coastal Management, 129, 44-48. https://doi.org/10.1016/j.ocecoaman.2016.05.006.

Pascoe, S., et al. (2014). Estimating the potential impact of entry fees for marine parks on dive tourism in South East Asia. Marine Policy, 47, 147-152. https://doi.org/10.1016/j.marpol.2014.02.017. 
Pham, T. T. T. (2020). Tourism in marine protected areas: Can it be considered as an alternative livelihood for local communities? Marine Policy, 115, 103891. https://doi.org/10.1016/j.marpol.2020.103891.

Polido, A., Joao, E., \& Ramos, T. B. (2014). Sustainability approaches and strategic environmental assessment in small islands: An integrative review. Ocean and Coastal Management, 96(1), 138-148.

Rocha, D., et al. (2020). Moving towards a sustainable cetacean-based tourism industry-A case study from Mozambique. Marine Policy, 120, 104048. https://doi.org/10.1016/j.marpol.2020.104048.

Romeril, M. (1988). Coastal tourism-An introduction. Tourism Recreation Research, 13(2), 3-4.

Tonazzinni, D., Fosse, J., Morales, E., González, A., Klarwein, S., Moukaddem, K., et al. (2019). Blue tourism. Towards a sustainable coastal and maritime tourism in world marine regions. Barcelona: Eco-Union.

Weaver, D. B. (2017). Core-periphery relationships and the sustainability paradox of small island tourism. Tourism Recreation Research, 42(1), 11-21. https://doi.org/10.1080/02508281.2016.1228559.

WEF. (2019). The Travel \& Tourism Competitiveness Report 2019. Travel and Tourism at a Tipping Point. Cologny/Geneva Switzerland: WEF.

Wong, P. P. (Ed.). (1993). Tourism vs environment: The case for coastal areas. Dordrecht: Springer.

Publisher's Note Springer Nature remains neutral with regard to jurisdictional claims in published maps and institutional affiliations. 